\title{
DAMPAK LATIHAN SINGLE LEG SPEED HOP DAN DOUBLE LEG SPEED HOP TERHADAP POWER TUNGKAI PADA PEMAIN BOLA VOLI
}

\author{
I Gede Dharma Utamayasa \\ Fakultas Pedagogik dan Psikologi, Universitas PGRI Adi Buana Surabaya \\ Email: dharmautamayasa@unipasby.ac.id
}

\begin{tabular}{l}
\hline Artikel Info \\
\hline Koresponden penulis: \\
I Gede Dharma Utamayasa \\
Email: \\
dharmautamayasa@,unipasby.ac.id \\
$\square$ Diterima 30 Oktober 2020 \\
$\square$ Direview 31 Oktober 2020 \\
$\square$ Disetujui 31 Oktober 2020 \\
$\square$ Dipublikasi 31 Oktober 2020
\end{tabular}

Kata Kunci:

Single leg speed hop, double leg speed hop, daya ledak otot tungkai

Keywords:

Single leg speed hop, double leg speed hop, power of leg muscle

\begin{abstract}
Abstrak
Penelitian ini bertujuan untuk mengetahui pengaruh latihan single leg speed hop dan double leg speed hop terhadap peningkatan power tungkai. Jenis penelitian ini adalah penelitian eksperimen semu (quasi experimental) rancangan the non-randomized pretest-posttest modified design. Sampel penelitian ini adalah 30 mahasiswa dengan Teknik ordinal pairing. Daya ledak otot tungkai diukur dengan menggunakan vertical jump test. Data dianalisis dengan uji $t$, uji anava satu jalur dan dilanjutkan uji least significant difference (LSD) dengan menggunakan SPSS 21.0. Hasil uji t dari dua latihan terdapat signifikansi pre test dan post test sebesar 0.000. Berdasarkan uji anava satu jalur diperoleh nilai signifikansinya sebesar 0.19 dan uji least significant difference (LSD) menunjukan bahwa terdapat perbedaan pengaruh antara kedua latihan. Jadi dapat disimpulkan bahwa latihan single leg speed hop dan double leg speed hop berpengaruh antara kedua latihan tersebut terhadap daya ledak otot tungkai pada mahasiswa pemain bola voli putra Universitas PGRI Adi Buana Surabaya.
\end{abstract}

\footnotetext{
Abstract

This study aims to determine the effect of single leg speed hop and double leg speed hop training on increasing leg power. The type of this research is quasi experimental research with the non-randomized pretest-posttest modified design. The sample of this research is 30 students with ordinal pairing technique. The explosive power of the leg muscles was measured using a vertical jump test. Data were analyzed by t test, one way anava test and continued with the least significant difference (LSD) test using SPSS 21.0. The t test results of the two exercises showed a significance of the pre test and post test of 0.000 . Based on the one-way ANOVA test, a significance value of 0.19 was obtained and the least significant difference (LSD) test showed that there was a difference in effect between the two exercises. So it can be concluded that the single leg speed hop and double leg speed hop exercises have an effect between the two exercises on the explosive power of leg muscles in male volleyball player students at PGRI Adi Buana University Surabaya.
} 
http://jurnal.unipasby.ac.id/index.php/stand/about/submissions jurnal.stand@unipasby.ac.id

\section{PENDAhUluAN}

Olahraga dapat dimulai sejak usia dini hingga usia lanjut dan dapat kita lakukan disetiap hari. Latihan fisik pada olahraga mengalami perubahan dan perkembangan dengan tujuan untuk pencegahan cidera dan peningkatan kualitas para atlet melalui program Latihan yang teratur dan terstruktur (Janupurba, 2011). Salah satu faktor dasar yang mempengaruhi kemampuan atlet dalam suatu cabang olahraga yang membutuhkan loncatan dan permainan adalah explosive power agar dapat melakukan suatu permainan secara optimal. Olahraga yang dimaksud salah satunya bola voli.

Latihan pliometrik telah terbukti meningkatkan power, akan tetapi belum banyak jurnal atau penelitian yang membandingkan Latihan single leg hop dan double leg hop dengan penambahan beban secara langsung dalam meningkatkan power. Penelitian terdahulu tentang pengaruh Latihan alternate leg bound dan double leg speed terhadap exsplosive power otot tungkai pada atlet bola voli putra Universitas PGRI Madiun dengan hasil penelitian tidak terdapat pengaruh yang signifikan antara pemberian treatment leg speed bound hops pada atlet bola voli putra Universitas PGRI Madiun (Ardyansyah, 2008), selain itu juga penelitian dari (Yatindra dkk, 2017) tentang Pengaruh Latihan Single Leg Speed Hop dan Double Leg Speed Hop Terhadap Daya Ledak Otot Tungkai Siswa pesrta Ekstrakurikuler Atletik (Lompat Jauh)
Tahun Pelajaran 2017/2018 terdapat hasil disimpulkan bahwa pelatihan single leg SMP N 4 Abiansemal tahun pelajaran 2017/2018 dan terdapat perbedaan pengaruh antara kedua pelatihan serta pelatihan double leg speed hop mempunyai pengaruh yang lebih baik dari pelatihan single leg speed hop.

Banyak beberapa faktor pendukung agar prestasi dapat diraih, mulai dari faktor teknik, taktik, kondisi fisik dan psikologi. Cabang olahraga memiliki kondisi fisik yang berbedabeda kondisi fisik yang disokuskan. Dalam cabang olahraga bolavoli misalnya, kondisi fisik yang berpengaruh besar adalah lompatan dan pukulan smash. Power lompatan yang notabene adalah explosive power otot tungkai, tidak serta merta diraih oleh pemain voli konevnsional. Beragam Latihan tersendiri yang dilakukan oleh pelatih bola voli agar explosive power otot tungkai atletnya dapat meningkat.

Berdasrakan pada permasalahan tersebut di atas, peneliti ingin menerapkan sebuah metode latihan single leg speed hop dengan double leg speed hop untuk meningkatkan power. Menurut Furqon dan Doewes (2002:34) mengatakan bahwa latihan single leg speed hop dilakukan dengan cara berdiri dengan satu kaki, posisi badan setengah jongkok kemudian meloncat ke atas depan dan mendarat dengan kedua kaki yang sama. Akan tetapi dari penelitian ini penulis mencoba melihat apakah terdapat perbedaan yang diberikan terhadap peningkatan power tungkai tersebut. Walaupun terlihat dari pembebanan Ketika melakukan 


\begin{tabular}{|c|c|c|}
\hline Unipa Sumalaga & $\begin{array}{l}\text { Journal STAND: Sports and Development } \\
\text { http://jurnal.unipasby.ac.id/index.php/stand/about/submissions } \\
\text { jurnal.stand@unipasby.ac.id }\end{array}$ & 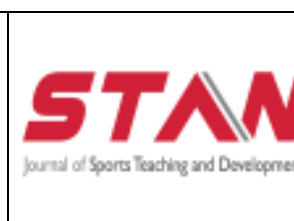 \\
\hline
\end{tabular}

single leg speed hop dibandingkan dengan double leg speed hop karena hanya menompang satu kaki dan dua kaki sehingga otot-otot yang terbentuk dan berkontraksi pun akan lebih kuat.

Namun semua itu membutuhkan pembuktian secara teoritis dan praktis.

\section{KAJIAN LITERATUR DAN PEGEMBANGAN HIPOTESIS}

Dua bentuk latihan pliometrik yaitu Single leg hop dan double leg speed hop, membentuk hasil latihan otot yang tetap sama yaitu mengarah pada ekstremitas bagian bawah seperti: gluteus maximus, minimus, gastrocemeus, hamstring, quadriceps, dll. Penelitian yang telah dilakukan oleh Graha (2010) mengatakan bahwa latihan single leg speed hop dan double leg speed hop memiliki pengaruh yang signifikan terhadap peningkatan daya ledak otot tungkai. Adapun keunggulan penelitian ini dengan penelitian yang lain diantaranya (1) dilihat dari segi gerakannya yang tidak terlalu sulit dilakukan, (2) kemungkinan cidera yang ditimbulkan sangat kecil, karena dilakukan pada lapangan yang rata, (3) pelatihan ini tidak memerlukan tempat yang luas, (4) Gerakan yang dilakukan menekankan pada loncatan untuk mencapai ketinggian maksimum dan kecepatan maksimum Gerakan kaki, yang sesuai dengan karakteristik cabang olahraga bola voli, dan (5) mengingat sampel yang digunakan pemain bolavoli diharapkan hasil dari penelitian ini mampu meningkatkan prestasi.

Ambarukmi, 2007:92 mengatakan bahwa power merupakan gabungan antara komponen kekuatan dan kecepatan yang dihasilkan sebuah otot atau sekelompok otot dalam waktu yang singkat. Untuk meningkatkan power perlu dirancang metode latihan yang khusus. Usia juga mempengaurhi power otot asumsinya adalah puncak power pada pinggul, lutut, dan ankle pada usia muda lebih besar tenaganya dibandingkan orang pada usia dewasa (Madigan, 2006). Latihan ini bekerja pada otot kaki atau tungkai diantaranya adalah gluteus (pinggul), hamstrings (otot paha bagian belakang), quadriceps (otot paha bagian depan), dan gastrocnemius (otot betis) (Delavier, 2010:93).

Latihan dengan penggunaan beban bebas memungkinkan bentuk latihan yang lebih efektif dari pada menggnakan beban mesin (machine weight training) (Racchman, 2012).

\section{METODE PENELITIAN}

Penelitian ini merupakan jenis penelitian eksperimen semu (quasi experimental). Pendekatan penelitian yang dilakukan pada penelitian ini adalah penelitian kuantitatif. Penelitian eksperimen adalah suatu penelitian yang dilakukan secara ketat untuk mengetahui varibel-variabel (Maksum, 2008:10). Salah satu ciri penelitian eksperimen yang paling umum adalah adanya perlakuan (treatment) terhadap subjek penelitian. 


\begin{tabular}{|c|c|}
\hline & Journal STAND: Sports and Development \\
umipa Sumalmya & http://jurnal.unipasby.ac.id/index.php/stand/about/submissions \\
jurnal.stand@unipasby.ac.id
\end{tabular}

Rancangan penelitian yang akan digunakan dalam penelitian ini adalah "the nonrandomized pre-test-post-test modified design" (Kanca, 2010:94). Rancangan yang dimaksud adalah:

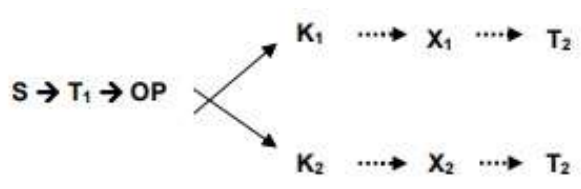

Gambar 01. Rancangan Penelitian

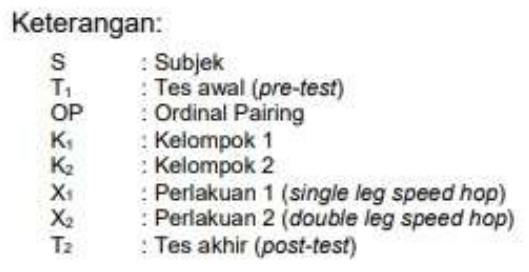

Berdasarkan rancangan penelitian di atas, maka pelaksanaan penelitian diawali dengan pemilihan populasi yang berjumlah 30 orang. Setelah menentukan subjek penelitian, kemudian diberikan pre-test $\left(\mathrm{T}_{1}\right)$ dengan perlakuan pengukuran vertical jump. Subjek penelitian dibagi menjadi 2 kelompok secara ordinal pairing (OP). kelompok perlakuan

$\left(\mathrm{K}_{1}\right)$ diberikan perlakuan single leg speed hop, kelompok perlakuan $\left(\mathrm{K}_{2}\right)$ diberikan perlakuan berupa perlakuan latihan double leg speed hop. Perlakuan akan diberikan selama 4 minggu atau 12 kali pelatihan dengan frekuensi latihan $3 \mathrm{kali}$ seminggu. Setelah 1 kali pelatihan kedua kelompok diberikan post-test $\left(\mathrm{T}_{2}\right)$ dengan tes yang sama yaitu vertical jump.

Analisis data yang harus dipenuhi adalah uji normalitas dan uji homogenitas. Untuk pengujian hipotesis menggunakan uji inferensial dengan uji-t independent dan uji anava satu jalur serta uji least significant difference (LSD) dengan bantuan SPSS 21 pada taraf signifikansi 0.05 .

\section{HASIL DAN PEMBAHASAN}

Deskripsi penelitian menjelaskan tentang hasil penelitian mulai dari hasil data deskritif, yiatu median, rata-rata, standar deviasi, varians dan penyajian data dalam bentuk distribusi untuk setiap variabel. Hasil analisis data dilakukan dengan manual dan menggunakan IBM SPSS Statistic 20 yang kemudian dijabarkan dalam data deskrtitif berikut.

\begin{tabular}{|c|c|c|c|c|c|}
\hline \multicolumn{6}{|c|}{ Tabel L. Descriptwe Stanlstics Ailwwate Leg Bosnd (ALB) } \\
\hline & $\mathrm{N}$ & $\begin{array}{l}\text { Minim } \\
\text { IX] }\end{array}$ & $\begin{array}{l}\text { Max } \\
\text { tram }\end{array}$ & Mean & Std Deviation \\
\hline Pretest & 15 & 39 & 54 & 45,10 & 4,232 \\
\hline Posttest & 15 & 39. & 55 & 46,11 & 4,375 \\
\hline $\begin{array}{l}\text { Valid N } \\
\text { (listwise) }\end{array}$ & 15 & & & & \\
\hline
\end{tabular}

Hasil skor pada kelompok eksperimen single leg speed hop sebelum pretest pemberian treatment nilai rata-rata 45,10 ; standar deviasi 4,232; nilai minimum 39 dan nilai maximum 54. Untuk hasil posttest pemberian treatment nilai rata-rata 46,11; standar deviasi 4,375; nilai minimum 39 dan nilai maximum 55. Data keompok 2 eksperimen double leg speed hop akan disajikan dalam table berikut;

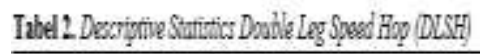

\begin{tabular}{|c|c|c|c|c|c|}
\hline & N & Minimum & Jinimun & $105 \mathrm{~m}$ & Sod. Deriatix \\
\hline Prevest & 15 & 42 & 53 & 4752 & 3,15 \\
\hline Portest & 15 & 43 & 54 & 48,00 & 2727 \\
\hline Valid N (istonse) & 15 & & & & \\
\hline
\end{tabular}




\section{Journal STAND: Sports and Development}

http://jurnal.unipasby.ac.id/index.php/stand/about/submissions jurnal.stand@unipasby.ac.id

Hasil skor pada kelompok eksperimen double leg speed hop sebelum pretest pemberian treatment nilai rata-rata 47,52 ; standar deviasi 3,125; nilai minimum 42 dan nilai maximum 53. Untuk hasil posttest pemberian treatment nilai rata-rata 48,00 ; standar deviasi 2,727; nilai minimum 43 dan nilai maximum 54.

Uji normalitas data dimaksudkan untuk memperlihatkan bahwa data sampel berasal dari populasi yang berdistribus normal. Uji yang dipilih untuk melihat kenormalan data dalam penelitian ini adalah uji kolmogorovsmirnov.

Tabel 3. Tes of Normality:

\begin{tabular}{|c|c|c|c|c|c|c|c|}
\hline & \multirow[t]{2}{*}{ Kelamsok } & \multicolumn{3}{|c|}{ Yolmugorow-Sminov' } & \multicolumn{3}{|c|}{ Shagiro-Wik } \\
\hline & & Statistic & df & Sig. & Statistic & $d f$ & Sig: \\
\hline & Elsperimen 1 & 153 & 15 & 210 & 927 & 15 & 487 \\
\hline \multirow[t]{2}{*}{ Pretest } & Essperimen_2 & 121 & 15 & $210^{\circ}$ & 996 & 15 &, 457 \\
\hline & Elsperimen_1 &, 168 & 15 & $210^{\circ}$ & 965 & 15 & .631 \\
\hline \multicolumn{2}{|c|}{ Portiest Eksperinen_2 } & 170 & 15 & $210^{\circ}$ &, 945 & 15 & .333 \\
\hline
\end{tabular}

Dasar hasil analisis di atas pada uji Kolmogorov-Smirnov dapat disimpulkan bahwa data tersebut berdistribusi normal, karena taraf signifikansi dari 0.05, maka pengolahan data dapat dilanjutkan untuk melewati uji homogenitas.

Uji homogenitas dilakukan bahwa dua atau lebih kelompok data sampel berasal dari populasi yang memiliki variansi yang sama. Uji homogenitas data ditampilkan dalam tabel 4 berikut:
Tabel 4. Uji Homogenitas

Skor Vertical Jump

\begin{tabular}{rrrrr}
\hline $\begin{array}{r}\text { Levene } \\
\text { Statistic }\end{array}$ & df1 & & df2 & \multicolumn{1}{c}{ Sig. } \\
\cline { 1 - 1 } 1,672 & & 2 & 41 &, 173 \\
\hline
\end{tabular}

Hasil data di atas, taraf signifikansi 0, 173 > 0.05 dinyatakan homogen, dan dapat dilanjutkan untuk untuk pengajuan hipotesis.

Pengujian hipotesis dilakukan berdasarkan hasil analisis data yang diperoleh sebelumnya, kemudian data diolah dan dianalisis secara statsistik menggunakan aplikasi IBM SPSS. Uji analisis yang digunakan untuk uji hipotesis adalah paired t test dan one way anava. Pada tabel 5 akan dipaparkan mengenai hasil uji hipotesis dengan uji-t sampel berpasangan menggunakan aplikasi IBM SPSS 21.

Tabel 5. Uji t

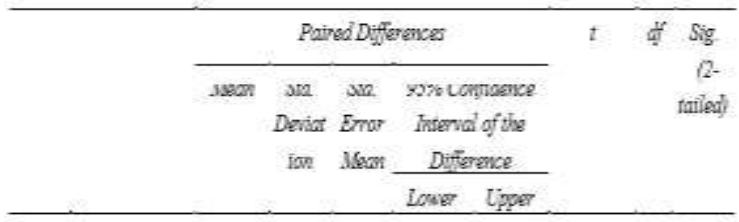

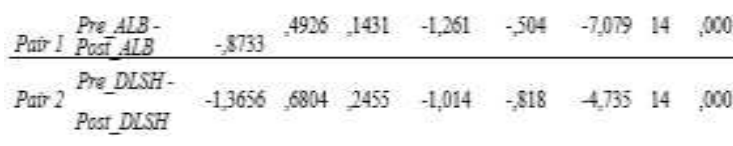

Setelah dilakukan pengujian hasil menunjukan nilai $p=0,000<a=0,05$ maka dapat disimpulkan $\mathrm{H} 1$ diterima dan $\mathrm{H} 0$ ditolak. Dengan kata lain ada perbedaan yang sangat signifikan power otot tungkai sebelum dan sesudah pemberian treatment. 


\section{Journal STAND: Sports and Development}

http://jurnal.unipasby.ac.id/index.php/stand/about/submissions jurnal.stand@unipasby.ac.id

Selanjutnya dilakukan analisis anava satu jaur untuk mengetahui ada tidaknya perbedaan pengaruh latihan single leg hop terhadap double leg hop perhatikan tabel 6 di bawah ini:

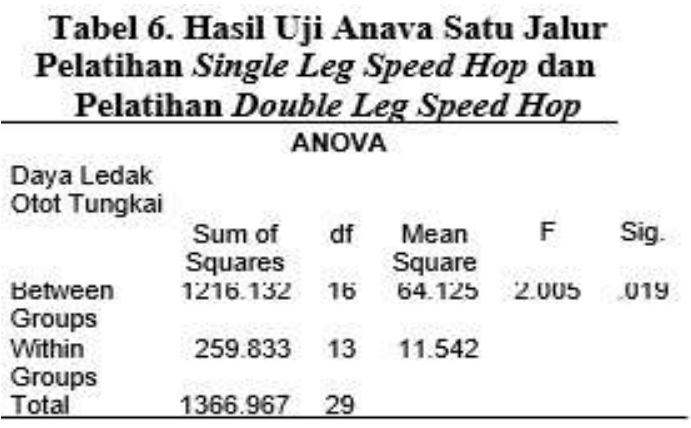

Hasil di atas menyatakan bahwa ada perbedaan yang bermakna pada nilai rata-rata daya ledak otot tungkai sebelum dan sesudah latihan. Dengan demikian hasil penelitian tersebut menunjukan bahwa perlakuan pada dua kelompok memberikan peningkatan yang bermakna terhadap daya ledak otot tungkai.

Tabel 07. Hasil Uji LSD Data Daya Ledak Otot Tungkai

\begin{tabular}{|c|c|c|c|c|c|c|}
\hline \multirow{2}{*}{$\begin{array}{l}\text { (I) } \\
\text { Kelomp } \\
\text { ok }\end{array}$} & \multirow{2}{*}{$\begin{array}{l}\text { (J) } \\
\text { Kelomp } \\
\text { ok }\end{array}$} & \multirow{2}{*}{$\begin{array}{l}\text { Mean } \\
\text { Oinferen } \\
\text { ce } \\
(1-\sqrt{ })\end{array}$} & \multirow[t]{2}{*}{$\begin{array}{l}\text { Sad. } \\
\text { Error }\end{array}$} & \multirow[t]{2}{*}{$\begin{array}{l}\text { SI } \\
\text { g. }\end{array}$} & \multicolumn{2}{|c|}{$\begin{array}{l}\text { \$5\% Canndence } \\
\text { interval }\end{array}$} \\
\hline & & & & & $\begin{array}{l}\text { Lower } \\
\text { Bound }\end{array}$ & $\begin{array}{l}\text { Upper } \\
\text { Bound }\end{array}$ \\
\hline $\begin{array}{l}\text { Single } \\
\text { Leg } \\
\text { Speed } \\
\text { Hop }\end{array}$ & $\begin{array}{l}\text { Double } \\
\text { Leg } \\
\text { Speed } \\
\text { Hop }\end{array}$ & $\begin{array}{l}20.2353 \\
3\end{array}$ & $\begin{array}{l}1.301 \\
92\end{array}$ & $0^{.00}$ & $\begin{array}{l}15.442 \\
31\end{array}$ & $\begin{array}{l}13.208 \\
12\end{array}$ \\
\hline $\begin{array}{l}\text { Double } \\
\text { Leg } \\
\text { Spe日d }\end{array}$ & $\begin{array}{l}\text { Singie } \\
\text { Leg } \\
\text { Speed }\end{array}$ & $\begin{array}{l}12.5233 \\
3\end{array}$ & $\begin{array}{l}1.438 \\
43\end{array}$ & $0_{0}^{.00}$ & $\begin{array}{l}14.748 \\
73\end{array}$ & $\begin{array}{l}15.714 \\
73\end{array}$ \\
\hline HOD & Hog & & & & & \\
\hline
\end{tabular}

Hasil dari tabel di atas terdapat perbedaan pengaruh antara latihan single leg speed hop dan double leg speed hop terhadap peningakatan power tungkai, maka dilanjutkan atau uji pembanding dengan menggunakan analisis LSD untuk mengetahui latihan mana yang lebih baik pengaruhnya terhadap peningkatan daya ledak otot tungkai dengan menggunakan SPSS IBM 21.0 pada taraf signifikansi 0.05

Penelitian Graha (2010) yang menyatakan bahwa terjadinya peningkatan power disebabkan karena meningkatkan jumlah protein kontraktil, filamen aktin dan miosin serta meningkatkan kekuatan jaringan ikat dan ligament. Sehingga dengan adanya peningkatan kekuatan otot serta kecepatan otot tungkai ini, maka secara langsung akan memberikan pengaruh yang besar terhadap peningkatan daya ledak tungkai.

Banyak faktor yang mendukung terjadinya peningkatan double leg speed hop dan single leg speed hop seperti terjadinya kontraksi otot dan mekanisme Gerakan dan keefektifan di dalam mekanisme pelaksanaannya. Pernyataan ini diperkuat oleh hasil penelitian Dewi (2014) yang menyatakan bahwa terjadinya peningkatan kekuatan otot disebabkan karena meningkatnya jumlah protein kontraktil, filamen aktin dan miosin serta meningkatkan kekuatan jaringan ikat dan ligamen.

Walaupun penelitian ini telah mampu untuk menjawab hipotesis, namun ada kendala yang dihadapi selama penelitian seperti: (1) berbenturannya jadwal latihan dan dengan jadwal kuliah yang semestinya dilakukan di pagi hari dilimpahkan ke sore hari. (2) subjek penelitian kurang paham mengenai latihan single leg speed hop dan doble leg hop tersebut. Sehingga seluruh sampel penelitian diberikan contoh dan diberikan kesempatan untuk mencoba sampai seluruh sampel paham. 


\begin{tabular}{|c|c|}
\hline & Journal STAND: Sports and Development \\
unttp://jurnal.unipasby.ac.id/index.php/stand/about/submissions \\
jurnal.stand@unipasby.ac.id
\end{tabular}

Hasil penelitian ini terbatas hanya pada pengaruh latihan single leg speed hop dan double leg speed hop terhadap peningkatan daya ledak otot tungkai.

\section{KESIMPULAN}

Berdasarkan hasil penelitian dan pembahasan, maka dapat diuraikan simpulan penelitian sebagai berikut:

1. Latihan single leg speed hop berpengaruh terhadap peningkatan daya ledak otot tungkai.

2. Latihan double leg hop berpengaruh yang sangat signifikan terhadap peningkatan daya ledak otot tungkai.

3. Terdapat perbedaan pengaruh antara dua latihan terhadap peningkatan daya ledak otot tungkai.

Adapun saran yang dapat diberikan kepada mahasiswa maupun pelatih olahraga sebagai berikut:

1. Bagi Pembina olahraga, pelatih olahraga serta pelaku olahraga lainnya dapat menggunakan rekomendasi latihan single leg hop dan double leg hop dengan baik sebagai salah satu komponen untuk meningkatkan daya ledak otot tungkai.

2. Bagi mahasiswa yang menjai subjek penelitian diharapkan latihan single leg hop dan double leg hop yang telah diperoleh agar di praktekan secara sungguh-sungguh dan kontinyu.

\section{REFERENSI}

Ambarukmi, D.H., Pasumey, P., Sidik, D.Z., Irianto, J.P., Dewanti, R.A., Sunyoto., Sulistiyanto, D. \& Harahap, Y. 2007. Pelatihan Pelatih Fisik Level 1. Jakarta: Kemenpora.

Ardyansyah Arief, 2018. Pengaruh latihan alternate leg bound dan double leg speed hop terhadap exsplosive power otot tungkai pada atlet bola voli putra universitas PGRI Madiun. Journal Power Of Sport. 1 (1) 2018, (1-11).

Delavier, F. (2010). Strength training anatomy. Third Edition. Germany: Human Kinetics.

Dewi, Ni Kadek Risna. 2014. Pengaruh Latihan Single Leg Hop Dan Latihan Double Leg Hop Terhadap Daya Ledak Otot Tungkai. Skripsi. Singaraja: Universitas Pendidikan Ganesha.

Furqon H,M dan Muchsin Doewes. 2002. Plaiometrik: Untuk Meningkatkan Power. Surakarta Program Pascasarjana Universitas Sebelas Maret.

Graha, Ali Satia. 2010. "Pengaruh Latihan Pliometrik Single Leg Hop Dan Double Leg Hop Terhadap Daya Ledak Otot Tungkai Dan Waktu Tempuh Pelari 110 Meter Gawang. Diakses tanggal 25 November 2020.

Janupurba, 2011. Tujuann dan Manfaat Olahraga. Jakarta: Salemba Medika.

Madigan, M.L. (2006). Age related differences in muscle power during single step balance 


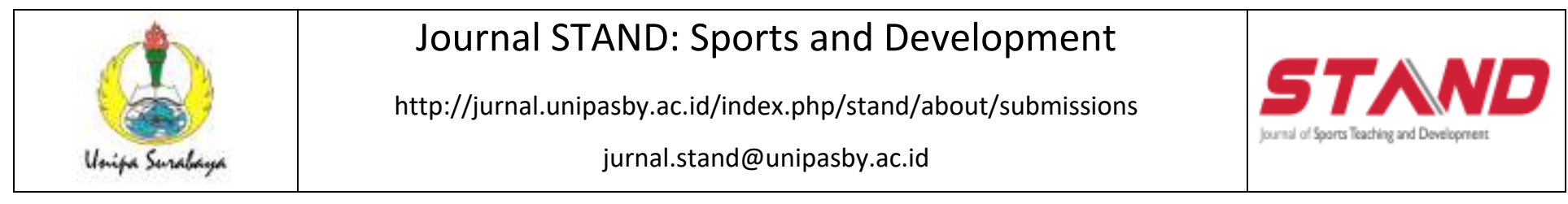

recovery. Journal of Applied

Biomechanics, 22 (3), 186-193.

Maksum, A (2012). Metodologi penelitian

dalam olahraga. Surabaya: Unesa

University Press.

Ranchman, A. (2012). Pengaruh latihan squat

dan leg press terhadap strength dan

hypertrophy otot tungkai. Jurnal

Multilateral, 13 (2), 88-102.

Yatindra IGAB, Iwan Swadesi, Sri Wahyunu

Dewi. 2017. Pengaruh Pelatihan Single

Leg Speed Hop Dan Double Leg Speed

Hop Terhadap Daya Ledak Otot Tungkai

Siswa Peserta Ekstrakurikuler Atletik

(Lompat jauh). Jurnal Ilmu Keolahragaan

Undiksha . p-ISSN: 2613-9693 | e-ISSN:

2613-9685. Volume 5 Nomor 3 Tahun

2017 